\title{
A CROSS-SECTIONAL ASSESSMENT OF SHARED-DECISION MAKING AMONG PATIENTS VISITING PUBLIC HEALTHCARE INSTITUTE OF QUETTA CITY, PAKISTAN
}

\author{
HIRA WAHEED ${ }^{1}$, SAJJAD HAIDER ${ }^{1}$, QAISER IQBAL ${ }^{1}$, ADNAN KHALID², \\ MOHAMED AZMI HASSALI ${ }^{3}$, MOHAMMAD BASHAAR ${ }^{4}$ AND FAHAD SALEEM ${ }^{1 *}$ \\ ${ }^{1}$ Faculty of Pharmacy \& Health Sciences, University of Balochistan, Quetta, Pakistan \\ ${ }^{2}$ Combined Military Hospital, Quetta, Pakistan \\ ${ }^{3}$ School of Pharmaceutical Sciences, Universiti Sains Malaysia, Pulau Pinang, Malaysia \\ ${ }^{4}$ Health Policy Analyst, SMART Afghan International Trainings \& Consultancy, Afghanistan
}

Published online: 31 May 2020

To cite this article: HIRA WAHEED, SAJJAD HAIDER, QAISER IQBAL, ADNAN KHALID, MOHAMED AZMI HASSALI, MOHAMMAD BASHAAR \& FAHAD SALEEM (2020) A cross-sectional assessment of shared-decision making among patients visiting public healthcare institute of Quetta City, Pakistan, Malaysian Journal of Pharmaceutical Sciences, 18(1): 15-29, https://doi.org/10.21315/mjps2020.18.1.2.

To link to this article: $\mathrm{https://doi.org/10.21315/mjps2020.18.1.2}$

Shared-decision making (SDM), occasionally called "participatory governance" is the approach in healthcare to ensure that patients have the right to participate effectively in the decision-making (DM) process. The aim of this research was to discuss the external aspect of SDM and put forward applicable solutions to ensure SDM at both patient and physician levels. A standardised validated nine-item SDM questionnaire (patient version SDM-Q-9) was employed. SPSS version 25 was used to perform data analysis. Multiple tests such as Mann-Whitney $U$ and Jonckheere-Terpstra were used. Kendall's Tau coefficient was used for interpretation of the significant relationship among all items of SDM-Q-9 and education. A total of 465 chronically ill patients took part, where majority (63.4\%) of patients was above the age of 47 . The cohort was dominated by females (67.5\%) with $92 \%$ of the sample was married. Majority (86.9\%) of the patient reported not involved in any decision. During analysis, considerable association was reported between gender and all items of SDM-Q-9, where more men were involved in SDM when compared with women. Our findings did produce significant association between education and SDM-Q-9, which reveals that increase in education can improve the SDM. SDM should not be limited to chronic or emergency in practice. Specific and tailored shared medical DM programmes must be developed for low literacy population implementation. SDM is to be supported at policy and operation levels.

Keywords: Shared-decision making, Cross-sectional assessment, Public healthcare institute, Quetta city, Pakistan

“Corresponding author: fahaduob@gmail.com

(C) Penerbit Universiti Sains Malaysia, 2020. This work is licensed under the terms of the Creative Commons Attribution (CC BY) (http://creativecommons.org/licenses/by/4.0/). 


\section{INTRODUCTION}

Shared-decision making (SDM), occasionally called "participatory governance" is the approach in healthcare to ensure that patients have the right to participate effectively in the decision-making (DM) process and the physicians hold themselves responsible to consult with patients (Yishai 2012). The goal of SDM is a collaborative endeavour between patient and doctor to empower patients to be involved as active partners in their health care decisions, especially in chronic diseases or preference-sensitive options where more than one intervention is available (Mincer, Adeogba and Bransford 2013; Veroff, Marr and Wennberg 2013). Patients desire to be involved in DM process and feel the ownership in their own medical decisions (Benbassat, Pilpel and Tidhar 1998), since patients' dissatisfaction arises when they are not being properly informed or involved in their illness and the options for treatment (Coulter and Cleary 2001). Patient participation is not expensive and a useful tool for return on investment and saving billions of dollars each year (Luke, Auraaen and Klazinga 2018).

To participate in medical DM, it is important to ensure that patient-centred education programmes are in place. Patient-centred education is a partnership between healthcare providers, patients and families to enhance information sharing among all members of a treatment team (Siddharthan et al. 2016; Stellefson, Dipnarine and Stopka 2013). Patientcentred education fosters communication (Stellefson, Dipnarine and Stopka 2013), improve drug adherence (Jack et al. 2009; Roberts 2002), reduce hospitalisation time (Roberts 2002), reduce medical costs and have long-term healthcare outcomes (Elwyn et al. 2000). However, some of the patients do not always want to be involved in making decision in regards to their treatment, and leave doctors to take a decision but since 50 years the trend has been changed by using different DM modules, the paternalistic model (relationship between patients and doctors) has been transformed to patient autonomy (HealthTalkOnline 2018). Some of these DM modules are: DECIDE (Guo 2008), Vroom-Yetton-Jago decision model (Field and Andrews 1998), OODA Loop (Wickramasinghe et al. 2009), recognitionprimed decision (RPD) model (Ross et al. 2004), Paired Comparison Analysis (Esposito et al. 2013; Ock et al. 2016; Pile 1964), The Ladder of Inference (Ross 1994), SHARE (Agency for Healthcare Research and Quality 2014), and SDM (Elwyn et al. 2010).

The above mentioned DM models are used in business disciplines; however, SDM model is well-suited in health care system. In order to measure the perceived level of involvement of both patient and physician in treatment DM, the shared decision making questionnaire (SDM-Q) was developed based on Elwyn's model (Elwyn and Charles 2001) and the observing patient involvement (OPTION) scale (Nicolai et al. 2012). Originally, the German SDM-Q has 24 questions and following major revisions, questions were reduced to nine and the new instrument was named, the SDM-Q-9. The SDM-Q-9 is translated into several languages (Rodenburg-Vandenbussche et al. 2015). This nine-item questionnaire was developed and tested in Germany (Kriston et al. 2010). There are two versions of the questionnaire, namely SDM-Q-9 and SDM-Q-Doc. The SDM-Q-9 (patient version) assess the degree to which patients are involved in the process of DM from patient perspective, while SDM-Q-Doc (physician version) measures to which extent physicians involved their patients in DM process from physician perspective.

In addition to SDM model, the World Health Organization (WHO) recognised "responsiveness" as one of three aims of health systems (Üstün et al. 2001). The concept of responsiveness in health systems has two dimensions: i) respect for human beings as persons, which involve respecting human dignity, privacy and independence and ii) client orientation, including prompt and well-timed service, adequate facilities, access to social support and freedom to choose providers. To assess the extent of "responsive" in terms

Malay J Pharm Sci, Vol. 18, No. 1 (2020): 15-29 
of respect for persons and client orientation, the WHO survey findings from 35 countries shows that United States, Switzerland, Luxembourg, Denmark, Germany, Japan, Canada, Norway, Netherlands and Sweden have the most responsive health systems (Üstün et al. 2001).

In the United Kingdom, the MAGIC (Making good decision in collaboration) programme aims to embed SDM in daily clinical practice. In this programme, posters in waiting rooms advise patients to ask these three questions: "What are my options?", "What are the benefits and harms?" and "How likely are these?". Rising patients' self-efficacy will improve their intent to share in DM (Gagnon et al. 2010). In the United States, the SDM has become an important element in health policy discussions (Center for Shared Decision Making 2018). To further strengthen this initiative several projects are in pipeline by the Foundation for Informed Medical Decision Making, alike at the Palo Alto Medical Foundation (Frosch et al. 2011; Informed Medical Decision Foundation 2018). Likewise, in Canada the SDM initiative has been used in healthcare, and further public plans are underway at various administrative levels (Légaré et al. 2011).

In Pakistan, as in many non-Western cultures, decisions about a patient's health care are often made by the family or the doctor (Jafarey and Farooqui 2005; Moazam 2000). A study conducted in Pakistan hospitals reported that majority of residents practiced SDM in their wards (Jameel, Noor and Ayub 2012). However, there is scarcity of information in general. Therefore, the aim of this cross-sectional survey is to employ SDM-Q-9 to measure the SDM process in patients attending the cardiac and medicine ward of tertiary hospital in Quetta, Pakistan.

\section{METHODOLOGY}

\section{Study Design and Setting}

A questionnaire-based, cross-sectional survey was conducted. Data was collected from patients attending the cardiac and medicine outpatient departments (OPDs) of Sandeman Provincial Hospital (SPH), Quetta, Pakistan. This hospital is the biggest government hospital of Quetta City and provides major healthcare facilities to the general population. Established in 1939 and located in the centre of the city, SPH is a tertiary care, teaching institute. Additionally, being public in nature, SPH is normally the institute of choice for majority of the local residents (Shahzad et al. 2018).

\section{Sampling Strategy, Study Population and Inclusion Criteria}

All patients suffering from chronic illness and attending the outpatient department of cardiac and medicine department of SPH Quetta were targeted for the study. Patients who were not willing to participate, those cannot read or write Urdu (official language of Pakistan) and immigrants, were excluded from the study. By keeping confidence interval of $95 \%, 5 \%$ margin of error and response distribution of $50 \%, 392$ patients were initially needed for the study. However, keeping a response rate of $20 \%$, final sample of 470 participants were included in the study (Daniel 2010). 


\section{Study Instrument}

Permission was taken from the developer to use the existing English version of SDM-Q-9 (patient version) (Kriston et al. 2010) and was translated in Urdu (National language of Pakistan) by a linguistic expert, the questionnaire was back translated into English by another expert to avoid any discrepancy in the two versions. Face and content validity was established by four physicians and four pharmacists, their opinion were taken into consideration before the pilot study. The questionnaire was subjected to pilot analysis comprising 30 participants. The questionnaire was declared reliable with an acceptable alpha value of 0.8 consequently used for the study.

\section{Data Analysis}

SPSS version 21 was used to perform data analysis. Mann-Whitney $U$ test was used for dichotomous variables that reported a significant association between gender and all items of SDM-Q-9. For variables other than dichotomous in nature, the Jonckheere-Terpstra test was used to find the trend of association. In addition, Kendall's Tau coefficient was used for interpretation of the significant relationship that revealed significant, weak association $(r<0.3)$ among all items of SDM-Q-9 and education.

\section{Ethics Approval}

Departmental Ethics Committee at the Faculty of Pharmacy and Health Sciences, University of Balochistan, Quetta approved the study. In addition, permission was also taken from the medical superintendent of SPH. Prior to data collection, the patients were informed about the research initiatives, confidentiality of their responses and their right to withdraw from the study with no penalty or effects on their treatment. Written consent was also taken from the patients.

\section{RESULTS}

\section{Demographic Characteristics of the Study Respondents}

Data was collected from 465 chronically ill patients with the response rate of $98.93 \%$ as shown in Table 1. Majority (63.4\%) of patients were above the age of 47 . The cohort was dominated by women $(314,67.5 \%)$. Ninety-two percent of the respondents were married and majority $(404,86.9 \%)$ was not involved in any decision regarding their treatment during their consultation. 
Table 1: Demographic characteristics of the study's respondents.

\begin{tabular}{|c|c|c|}
\hline Characteristics & Frequency & Percentage \\
\hline $\begin{array}{l}\text { Age }(51.62 \pm 12.71) \\
\quad 18-27 \\
\quad 28-37 \\
\quad 38-47 \\
\quad>47\end{array}$ & $\begin{array}{r}5 \\
68 \\
97 \\
295\end{array}$ & $\begin{array}{r}1.1 \\
14.6 \\
20.9 \\
63.4\end{array}$ \\
\hline $\begin{array}{l}\text { Gender } \\
\text { Man } \\
\text { Woman }\end{array}$ & $\begin{array}{l}151 \\
314\end{array}$ & $\begin{array}{l}32.5 \\
67.5\end{array}$ \\
\hline $\begin{array}{l}\text { Marital status } \\
\text { Married } \\
\text { Unmarried }\end{array}$ & $\begin{array}{r}429 \\
36\end{array}$ & $\begin{array}{r}92.3 \\
7.7\end{array}$ \\
\hline $\begin{array}{l}\text { Disease state } \\
\text { Arthritis } \\
\text { Chronic kidney disease } \\
\text { Hypertension } \\
\text { Coronary heart disease } \\
\text { Diabetes mellitus type II } \\
\text { Asthma }\end{array}$ & $\begin{array}{r}70 \\
66 \\
152 \\
79 \\
76 \\
22\end{array}$ & $\begin{array}{r}15.1 \\
14.2 \\
32.7 \\
17.0 \\
16.3 \\
4.7\end{array}$ \\
\hline $\begin{array}{l}\text { Education* } \\
\text { Un-educated } \\
\text { Religious education } \\
\text { Primary } \\
\text { Matriculation } \\
\text { Intermediate } \\
\text { Undergraduate } \\
\text { Post-graduate }\end{array}$ & $\begin{array}{r}256 \\
30 \\
49 \\
36 \\
27 \\
38 \\
28\end{array}$ & $\begin{array}{r}55.1 \\
6.5 \\
10.5 \\
7.7 \\
5.8 \\
8.2 \\
6.0\end{array}$ \\
\hline $\begin{array}{l}\text { Occupation }^{* *} \\
\text { Unemployed } \\
\text { Housewife } \\
\text { Government employee } \\
\text { Private sector employee } \\
\text { Private business }\end{array}$ & $\begin{array}{r}69 \\
282 \\
58 \\
36 \\
18\end{array}$ & $\begin{array}{r}14.8 \\
60.6 \\
12.5 \\
7.7 \\
3.9\end{array}$ \\
\hline $\begin{array}{l}\text { Monthly income } \\
\text { Nil } \\
\begin{array}{l}1,000-10,000 \\
10,001-20,000 \\
20,001-30,000 \\
\text { Above } 30,000\end{array}\end{array}$ & $\begin{array}{r}353 \\
6 \\
7 \\
27 \\
72\end{array}$ & $\begin{array}{r}75.9 \\
1.3 \\
1.5 \\
5.8 \\
15.5\end{array}$ \\
\hline $\begin{array}{l}\text { Locality } \\
\text { Rural } \\
\text { Urban }\end{array}$ & $\begin{array}{l}134 \\
331\end{array}$ & $\begin{array}{l}28.8 \\
71.2\end{array}$ \\
\hline $\begin{array}{l}\text { Please indicate which decisio } \\
\text { No decision was made } \\
\text { About medication } \\
\text { About surgery/ operation }\end{array}$ & $\begin{array}{r}404 \\
26 \\
35\end{array}$ & $\begin{array}{r}86.9 \\
5.6 \\
7.5\end{array}$ \\
\hline
\end{tabular}

Notes: Missing data $\left({ }^{*}=1 ;{ }^{* *}=2\right)$ 


\section{Response to SDM-Q-9}

As shown in Table 2, majority of patients completely disagreed to all items of SDM-Q-9 with response ranging from $79.6 \%-84.3 \%$. Only $19(4.1 \%)$ of the patients agreed that their physician asked for the treatment option they will prefer. Additionally, different treatment options were weighed by the physicians and patients in only $20(4.3 \%)$ of the cases. In only $5 \%$ of the cases, the patients were informed about different treatment options available for their condition and mutual consensus on how to proceed was agreed by $26(5.6 \%)$ of the participants.

Table 2: Response to SDM-Q-9.

\begin{tabular}{|c|c|c|c|c|c|c|c|c|c|c|c|c|}
\hline \multirow{2}{*}{$\begin{array}{l}\text { Items in } \\
\text { SDM-Q-9 }\end{array}$} & \multicolumn{2}{|c|}{ CD } & \multicolumn{2}{|c|}{ SD } & \multicolumn{2}{|c|}{ SWD } & \multicolumn{2}{|c|}{ SWA } & \multicolumn{2}{|c|}{ SA } & \multicolumn{2}{|c|}{ CA } \\
\hline & $\mathrm{N}$ & $\%$ & $\mathbf{N}$ & $\%$ & $\mathbf{N}$ & $\%$ & $\mathbf{N}$ & $\%$ & $\mathbf{N}$ & $\%$ & $\mathbf{N}$ & $\%$ \\
\hline 1 & 387 & 83.2 & 8 & 1.7 & 2 & 0.4 & 23 & 4.9 & 9 & 1.9 & 36 & 7.7 \\
\hline 2 & 392 & 84.3 & 9 & 1.9 & 13 & 2.8 & 13 & 2.8 & 12 & 2.6 & 26 & 5.6 \\
\hline 3 & 392 & 84.3 & 15 & 3.2 & 10 & 2.2 & 10 & 2.2 & 15 & 3.2 & 23 & 4.9 \\
\hline 4 & 386 & 83.0 & 14 & 3.0 & 8 & 1.7 & 19 & 4.1 & 11 & 2.4 & 27 & 5.8 \\
\hline 5 & 370 & 79.6 & 13 & 2.8 & 9 & 1.9 & 27 & 5.8 & 18 & 3.9 & 28 & 6.0 \\
\hline 6 & 386 & 83.0 & 17 & 3.7 & 13 & 2.8 & 18 & 3.9 & 12 & 2.6 & 19 & 4.1 \\
\hline 7 & 385 & 82.8 & 15 & 3.2 & 10 & 2.2 & 18 & 3.9 & 17 & 3.7 & 20 & 4.3 \\
\hline 8 & 388 & 83.4 & 15 & 3.2 & 10 & 2.2 & 15 & 3.2 & 15 & 3.2 & 22 & 4.7 \\
\hline 9 & 388 & 83.4 & 16 & 3.4 & 7 & 1.5 & 16 & 3.4 & 12 & 2.6 & 26 & 5.6 \\
\hline
\end{tabular}

Notes:

1 My doctor made clear that decision needs to be made.

2 My doctor wanted to know exactly how I want to be involved in making the decision.

3 My doctor told me that there are different options for treating my medical condition.

4 My doctor precisely explained the advantages and disadvantages of the treatment options.

5 My doctor helped me understand all the information.

6 My doctor asked me which treatment option I prefer.

7 My doctor and I thoroughly weighed the different treatment options.

8 My doctor and I selected a treatment option together.

9 My doctor and I reached an agreement on how to proceed.

$\mathrm{CD}=$ completely disagree; $\mathrm{SD}=$ strongly disagree; $\mathrm{SWD}=$ somewhat disagree; $\mathrm{SWA}=$ somewhat agree; $\mathrm{SA}=$ strongly agree; $\mathrm{CA}=$ completely agree

\section{Association between SDM and Demographic Characteristics}

The association between demographic variables and SDM-Q-9 items was carried out through non-parametric analysis. The Mann-Whitney $U$ test was used for dichotomous variables that reported a significant association between gender and all items of SDM-Q-9. The mean rank interpretation revealed that men were more involved in SDM regarding their treatment when compared with women. However, no significant association was reported between SDM-Q-9 and other dichotomous variables. For variables other than dichotomous in nature, the Jonckheere-Terpstra test was used to find the trend of association. Education was significantly associated with SDM-Q-9. The Kendall's Tau coefficient was used for interpretation of the significant relationship that revealed significant, weak association $(r<0.3)$ among all items of SDM-Q-9 and education. Hence it is concluded that with an 
increase in education, there are possibilities of increase in SDM. In addition, significant association between first six items of SDM-Q-9 and monthly income of patients was also reported. Weak association $(r<0.3)$ was reported revealing involvement in shared-decision process with an increase in income (Table 3 ).

Table 3: Association among study items (SDM-Q-9) and demographic variables

\begin{tabular}{|c|c|c|c|c|c|c|c|c|}
\hline \multirow{2}{*}{$\begin{array}{l}\text { Items in } \\
\text { SDM-Q-9 }\end{array}$} & \multicolumn{8}{|c|}{$P$-value } \\
\hline & Age* $^{*}$ & Gender** & $\begin{array}{l}\text { Marital } \\
\text { status }^{* *}\end{array}$ & Locality** & $\begin{array}{c}\text { Disease } \\
\text { state }^{*}\end{array}$ & Education* & Occupation* & Income* \\
\hline 1 & 0.881 & $<0.01$ & 0.906 & 0.897 & 0.234 & 0.003 & 0.393 & 0.015 \\
\hline 2 & 0.990 & $<0.01$ & 0.707 & 0.562 & 0.218 & 0.002 & 0.393 & 0.020 \\
\hline 3 & 0.673 & $<0.01$ & 0.774 & 0.557 & 0.361 & 0.001 & 0.331 & 0.015 \\
\hline 4 & 0.974 & $<0.01$ & 0.737 & 0.174 & 0.213 & $<0.01$ & 0.296 & 0.017 \\
\hline 5 & 0.818 & $<0.01$ & 0.831 & 0.608 & 0.123 & 0.002 & 0.110 & 0.008 \\
\hline 6 & 0.742 & 0.001 & 0.584 & 0.852 & 0.215 & 0.004 & 0.386 & 0.047 \\
\hline 7 & 0.484 & 0.001 & 0.894 & 0.385 & 0.376 & 0.001 & 0.485 & 0.058 \\
\hline 8 & 0.440 & 0.001 & 0.998 & 0.797 & 0.546 & 0.002 & 0.527 & 0.068 \\
\hline 9 & 0.968 & 0.001 & 0.656 & 0.871 & 0.253 & 0.007 & 0.425 & 0.075 \\
\hline
\end{tabular}

Notes: *Jonckheere-Terpstra test; ${ }^{\star *}$ Mann-Whitney U test

My doctor made clear that decision needs to be made.

My doctor wanted to know exactly how I want to be involved in making the decision.

My doctor told me that there are different options for treating my medical condition.

My doctor precisely explained the advantages and disadvantages of the treatment options.

My doctor helped me understand all the information.

My doctor asked me which treatment option I prefer.

My doctor and I thoroughly weighed the different treatment options.

My doctor and I selected a treatment option together.

My doctor and I reached an agreement on how to proceed.

\section{DISCUSSION}

SDM is a central to shaping effective healthcare system and at patient level; it has the potential to save lives through safety and quality of health services (WHO 2016). Therefore, in this study we examined the effect of SDM on healthcare quality in Quetta among patients using SDM.

However, considering the impact of SDM of healthcare quality, unfortunately, our results showed that majority of cohort was not involved in any decision regarding their treatment during their consultation, which is similar to prior studies, where patient involvement in DM is poor worldwide (Deber et al. 2007; McKinstry 2000). But in reality, patients prefer to be offered choices and to be asked their opinions in regards to their disease/treatment (Levinson et al. 2005). Research conducted in Malaysia reveals that

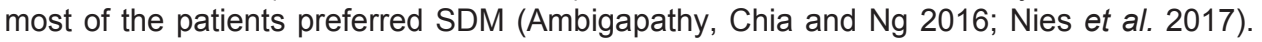
In Japan and United States, majority of patients with cancer preferred SDM (Bruera et al. 2001; Schaede et al. 2017; Singh et al. 2010). Therefore, active advocacy at all levels even at patient level (self-advocacy) is necessary to ensure SDM, patient's empowerment (Elwyn, Tilburt and Montori 2013; Shay and Lafata 2014) and healthcare quality. 
So the question is, if the governments are committed towards health quality at policy level, then why patients are not or less involved in DM process? Literature has identified three main barriers towards SDM: time constraints (Stacey et al. 2006; Whelan et al. 2003), lack of applicability due to patient characteristics/preferences (Cabana et al. 1999) and the clinical situation (Légare et al. 2008). Therefore, it is imperative that while developing or structuring SDM, it is advised that healthcare providers should keep the individual differences in patient preferences in consideration (Arora and McHorney 2000; Robinson and Thomson 2001) and employ DM models. Research revealed that despite existing barriers there are multiple facilitators to SDM like provider motivation, positive impact on the clinical process and patient outcomes (Légaré et al. 2008). Literature review shows that physicians have positive attitudes toward SDM in their clinical practice (Pollard, Bansback and Bryan 2015). That is why SDM and production of SDM training programmes as an effective tool gaining acknowledgement and growing fast in diverse cultures and healthcare setting, in Asia (Légaré et al. 2008) and rest of the world (Diouf et al. 2016).

Significant association was reported between gender and all items of SDM-Q-9 in our study. More men were involved in SDM regarding their treatment when compared with women. Past research has shown that DM could be influenced by personal and social attributes, such as gender, since women can't share their preferences with doctor as compared to men (Street Jr 1991; Willems et al. 2005). However, gender differences in communication styles between doctors and patients have been hypothesised to impact patient care, but the degree remains unclear (Sandhu et al. 2009). Other researchers believe that both, men and women cautiously process information, think logically about the alternatives, predict results, evaluate the consequences, solve the problems and examine all the decision stages (Sanz de Acedo Lizárraga et al. 2007) and there is no influence of gender on DM (Uzonwanne 2016). In the Asian culture, the DM is often left purely to the doctors or other family members despite of gender differences. In Pakistan still the paternalistic model of DM is a trend. Similarly, literature from Kashmir and Japan reveals that patients are willing to accept what their doctors choose for them and the doctors are pleased with their role as decision-maker (Miyashita et al. 2006; Yousuf et al. 2007). Moreover, researchers from Hong Kong feel that patients and doctors to be more enthusiastic to acknowledge the role of families in DM (Chan 2004).

During statistical analysis, we found a significant association between education and SDM-Q-9, which reveals that increase in education, can improve the SDM. Past research has shown that patients with less educational report less interest in SDM (Kiesler and Auerbach 2006). The importance of education interventions were found effective at increasing the implementation of SDM (Chen et al. 2016). Insufficient health literacy and poor physicianpatient communication are two major healthcare challenges adversely affecting DM and consequently contributing to poor treatment decision, drug adherence and high healthcare costs (Kindig, Panzer and Nielsen-Bohlman 2004). Similarly, there is a strong correlation between quality of physician-patient communication and patient satisfaction and positive health outcomes (Stewart 1995). One of the past studies demonstrated that perceived lack of knowledge is a major barrier to SDM (Belcher et al. 2006) and another study revealed that statistical (numbers) illiteracy hampers SDM (Gaissmaier and Gigerenzer 2008). Previous studies indicated that low literacy skills are strongly associated with lower educational levels (Kim et al. 2001). An economically sound and literate population, properly trained doctors and commitment towards SDM are essential prerequisites for establishing DM in healthcare facilities. Therefore, these findings suggest that health literacy is the cornerstone in effective DM. The health literacy definitions focus on individual skills to obtain process and understand health information and services necessary to make appropriate health decisions (Sørensen et al. 2012). In a nutshell, the SDM model is well-suited and appropriate within real-world

Malay J Pharm Sci, Vol. 18, No. 1 (2020): 15-29 
healthcare systems (e.g. nursing, over-the-counter consumer purchases, emergency, chronic illness management and mental illnesses) and thus patients can expect further individualised and personal treatment plans (Tay, Massaro and Vlaev 2017). With all these advances in techniques and tools to encourage patient participation in SDM, challenges still exist in developing tools for patients with lower literacy, poor health knowledge, limited involvement in health decisions and poor health outcomes (McCaffery, Smith and Wolf 2010). SDM practices at clinical level have direct impact over healthcare quality. Therefore, the health care providers and policy makers should strive to strengthen and promote the SDM at primary, secondary and tertiary healthcare settings.

\section{CONCLUSION}

As part of healthcare services, SDM should not be limited to chronic, emergency medical situation or where multiple choices are considered. Respect and access to critical information is the right of both doctor and patient. In SDM, the doctor, patient and family are obligated to give one another realistic information about the illness and treatment plan. The policy maker and healthcare providers should put SDM into practice and for the low literacy population, specific and tailored shared medical DM programmes must be developed. For implementation and success of SDM the political and institutional will and support is needed.

\section{FINANCIAL DISCLOSURE AND CONFLICT OF INTEREST}

No funding was received for the study. The authors have no conflict of interest to declare.

\section{REFERENCES}

AGENCY FOR HEALTHCARE RESEARCH AND QUALITY. (2014) The SHARE approach essential steps of shared decision making: Expanded reference guide with sample conversation starters, https://www.ahrq.gov/sites/default/files/wysiwyg/ professionals/education/curriculum-tools/shareddecisionmaking/tools/tool-2/share-tool2. pdf (3 March 2019).

AMBIGAPATHY, R., CHIA, Y. C. \& NG, C. J. (2016) Patient involvement in decisionmaking: a cross-sectional study in a Malaysian primary care clinic, BMJ Open, 6: e010063. https://doi.org/10.1136/bmjopen-2015-010063

ARORA, N. K. \& MCHORNEY, C. A. (2000) Patient preferences for medical decision making: Who really wants to participate?, Medical Care, 38(3): 335-341. https://doi.org/ 10.1097/00005650-200003000-00010

BELCHER, V. N., FRIED, T. R., AGOSTINI, J. V. \& TINETTI, M. E. (2006) Views of older adults on patient participation in medication-related decision making, Journal of General Internal Medicine, 21: 298-303. https://doi.org/10.1111/j.1525-1497.2006.00329.x

BENBASSAT, J., PILPEL, D. \& TIDHAR, M. (1998) Patients' preferences for participation in clinical decision making: A review of published surveys, Behavioral Medicine, 24(2): 81-88. https://doi.org/10.1080/08964289809596384 
BRUERA, E., SWEENEY, C., CALDER, K., PALMER, L. \& BENISCH-TOLLEY, S. (2001) Patient preferences versus physician perceptions of treatment decisions in cancer care, Journal of Clinical Oncology, 19(11): 2883-2885. https://doi.org/10.1200/ JCO.2001.19.11.2883

CABANA, M. D., RAND, C. S., POWE, N. R., WU, A. W., WILSON, M. H., ABBOUD, P.-A. C. et al. (1999) Why don't physicians follow clinical practice guidelines?: A framework for improvement, JAMA, 282: 1458-1465. https://doi.org/10.1001/jama.282.15.1458

CHAN, H. M. (2004) Informed consent Hong Kong style: An instance of moderate familism, The Journal of Medicine and Philosophy, 29(2): 195-206. https://doi.org/10.1076/ jmep.29.2.195.31508

CHEN, E. H., KANZARIA, H. K., ITAKURA, K., BOOKER-VAUGHNS, J., YADAV, K. \& KANE, B. G. (2016) The role of education in the implementation of shared decision making in emergency medicine: a research agenda, Academic Emergency Medicine, 23(12): 13621367. https://doi.org/10.1111/acem.13059

COULTER, A. \& CLEARY, P. D. (2001) Patients' experiences with hospital care in five countries, Health Affairs, 20(3): 244-252. https://doi.org/10.1377/hlthaff.20.3.244

CENTER FOR SHARED DECISION MAKING (CSDM). (2018) Center for shared decision making at Dartmouth Hitchcock Medical Center, https://med.dartmouth-hitchcock.org/ csdm_toolkits.html (1 March, 2019).

DANIEL, W. W. (2010). Biostatistics: Basic concepts and methodology for the health sciences. (NY, USA: John Wiley \& Sons).

DEBER, R. B., KRAETSCHMER, N., UROWITZ, S. \& SHARPE, N. (2007) Do people want to be autonomous patients? Preferred roles in treatment decision-making in several patient populations, Health Expectations, 10(3): 248-258. https://doi.org/10.1111/j.1369 $-7625.2007 .00441 . x$

DIOUF, N. T., MENEAR, M., ROBITAILlE, H., GUÉRARD, G. P. \& LÉGARÉ, F. (2016) Training health professionals in shared decision making: Update of an international environmental scan, Patient Education and Counseling, 99(11): 1753-1758. https://doi. org/10.1016/j.pec.2016.06.008

ELWYN, G. \& CHARLES, C. (2001) Shared decision making: The principles and the competences, Evidence-based patient choice: inevitable or impossible?, 118-143 (Oxford: Oxford University Press).

ELWYN, G., EDWARDS, A., KINNERSLEY, P. \& GROL, R. (2000) Shared decision making and the concept of equipoise: The competences of involving patients in healthcare choices, British Journal of General Practice, 50: 892-899.

ELWYN, G., LAITNER, S., COULTER, A., WALKER, E., WATSON, P. \& THOMSON, R. (2010) Implementing shared decision making in the NHS, British Medical Journal, 341: c5146. https://doi.org/10.1136/bmj.c5146

Malay J Pharm Sci, Vol. 18, No. 1 (2020): 15-29 
ELWYN, G., TILBURT, J. \& MONTORI, V. (2013) The ethical imperative for shared decision-making, European Journal for Person Centered Healthcare, 1(1): 129-131. https:// doi.org/10.5750/ejpch.v1i1.645

ESPOSITO, S., PELULLO, C. P., AGOZZINO, E. \& ATTENA, F. (2013) A paired-comparison intervention to improve quality of medical records, Journal of Hospital Administration, 2(3): 91-96. https://doi.org/10.5430/jha.v2n3p91

FIELD, R. H. \& ANDREWS, J. (1998) Testing the incremental validity of the VroomJago versus Vroom-Yetton models of participation in decision making, Journal of Behavioral Decision Making, 11(4): 251-261. https://doi.org/10.1002/(SICI)10990771(1998120)11:4\%3C251::AID-BDM300\%3E3.0.CO;2-2

FROSCH, D. L., MOULTON, B. W., WEXLER, R. M., HOLMES-ROVNER, M., VOLK, R. J. \& LEVIN, C. A. (2011) Shared decision making in the United States: Policy and implementation activity on multiple fronts, The Journal of Evidence and Quality in Health Care, 105(4): 305-312. https://doi.org/10.1016/j.zefq.2011.04.004

GAGNON, S., LABRECQUE, M., NJOYA, M., ROUSSEAU, F., ST-JACQUES, S. \& LÉGARÉ, F. (2010) How much do family physicians involve pregnant women in decisions about prenatal screening for Down syndrome?, Prenatal Diagnosis: Published in Affiliation with the International Society for Prenatal Diagnosis, 30(2): 115-121. https://doi.org/10.1002/ pd.2421

GAISSMAIER, W. \& GIGERENZER, G. (2008) Statistical illiteracy undermines informed shared decision making, Zeitschrift für Evidenz, Fortbildung und Qualität im Gesundheitswesen, 102(7): 411-413. https://doi.org/10.1016/j.zefq.2008.08.013

GUO, K. L. (2008) DECIDE: A decision-making model for more effective decision making by health care managers, The Health Care Manager, 27(2): 118-127. https://doi .org/10.1097/01.HCM.0000285046.27290.90

HEALTHTALKONLINE. (2018) Shared decision making, http://www.healthtalk.org/peoplesexperiences/improving-health-care/shared-decision-making/what-shared-decision-making (2 March, 2019).

INFORMED MEDICAL DECISIONS FOUNDATION (IMDF). (2018) Informed Medical Decisions Foundation, https://www.healthwise.org/solutions/care-transformation.aspx (5 March, 2019).

JACK, B. W., CHETTY, V. K., ANTHONY, D., GREENWALD, J. L., SANCHEZ, G. M., JOHNSON, A. E. et al. (2009) A reengineered hospital discharge program to decrease rehospitalization: A randomized trial, Annals of Internal Medicine, 150(3): 178-187. https:// doi.org/10.7326/0003-4819-150-3-200902030-00007

JAFAREY, A. M. \& FAROOQUI, A. (2005) Informed consent in the Pakistani milieu: The physician's perspective, Journal of Medical Ethics, 31(2): 93-96. https://doi.org/10.1136/ jme.2002.002220 
JAMEEL, A., NOOR, S. M. \& AYUB, S. (2012) Survey on perceptions and skills amongst postgraduate residents regarding breaking bad news at teaching hospitals in Peshawar, Pakistan, Journal of the Pakistan Medical Association, 62: 585-589.

KIESLER, D. J. \& AUERBACH, S. M. (2006) Optimal matches of patient preferences for information, decision-making and interpersonal behavior: Evidence, models and interventions, Patient Education and Counseling, 61(3): 319-341. https://doi.org/10.1016/j. pec.2005.08.002

KIM, S. P., KNIGHT, S. J., TOMORI, C., COLELLA, K. M., SCHOOR, R. A., SHIH, L. et al. (2001) Health literacy and shared decision making for prostate cancer patients with low socioeconomic status, Cancer Investigation, 19(7): 684-691. https://doi.org/10.1081/ CNV-100106143

KINDIG, D. A., PANZER, A. M. \& NIELSEN-BOHLMAN, L. (2004) Health literacy: A prescription to end confusion (National Academies Press).

KRISTON, L., SCHOLL, I., HÖLZEL, L., SIMON, D., LOH, A. \& HÄRTER, M. (2010) The 9-item shared decision making questionnaire (SDM-Q-9). Development and psychometric properties in a primary care sample, Patient Education and Counseling, 80(1): 94-99. https://doi.org/10.1016/j.pec.2009.09.034

LÉGARÉ, F., RATTÉ, S., GRAVEL, K. \& GRAHAM, I. D. (2008) Barriers and facilitators to implementing shared decision-making in clinical practice: update of a systematic review of health professionals' perceptions, Patient Education and Counseling, 73(3): 526-535. https://doi.org/10.1016/j.pec.2008.07.018

LÉGARÉ, F., STACEY, D., FOREST, P.-G. \& COUTU, M.-F. (2011) Moving SDM forward in Canada: Milestones, public involvement and barriers that remain, Zeitschrift für Evidenz, Fortbildung und Qualität im Gesundheitswesen, 105(4): 245-253. https://doi.org/10.1016/j.zefq.2011.04.011

LEVINSON, W., KAO, A., KUBY, A. \& THISTED, R. A. (2005) Not all patients want to participate in decision making: a national study of public preferences, Journal of General Internal Medicine, 20: 531-535. https://doi.org/10.1111/j.1525-1497.2005.04101.x

LUKE, S., ANE AURAAEN \& KLAZINGA, N. (2018). The economics of patient safety in primary and ambulatory care, https://www.oecd.org/health/health-systems/The-Economicsof-Patient-Safety-in-Primary-and-Ambulatory-Care-April2018.pdf (1 March 2019).

MCCAFFERY, K. J., SMITH, S. K. \& WOLF, M. (2010) The challenge of shared decision making among patients with lower literacy: a framework for research and development, Medical Decision Making, 30: 35-44. https://doi.org/10.1177/0272989X09342279

MCKINSTRY, B. (2000) Do patients wish to be involved in decision making in the consultation? A cross sectional survey with video vignettes, British Medical Journal, 321: 867-871. https://doi.org/10.1136/bmj.321.7265.867 
MINCER, S., ADEOGBA, S. \& BRANSFORD, R. (2013) Shared decision-making (SDM) toolkit: Train-the-trainer tools for teaching SDM in the classroom and clinic, MedEdPORTAL Publications, 9: 9413. https://doi.org/10.15766/mep_2374-8265.9413

MIYASHITA, M., HASHIMOTO, S., KAWA, M., SHIMA, Y., KAWAGOE, H., HASE, T. et al. (2006) Attitudes toward disease and prognosis disclosure and decision making for terminally ill patients in Japan, based on a nationwide random sampling survey of the general population and medical practitioners, Palliative \& Supportive Care, 4(4): 389-398. https://doi.org/10.1017/S1478951506060482

MOAZAM, F. (2000) Families, patients, and physicians in medical decisionmaking: A Pakistani perspective, Hastings Center Report, 30(6): 28-37. https://doi.org/10.2307/3528451

NICOLAI, J., MOSHAGEN, M., EICH, W. \& BIEBER, C. (2012) The OPTION scale for the assessment of shared decision making (SDM): Methodological issues, Zeitschrift für Evidenz, Fortbildung und Qualität im Gesundheitswesen, 106(4): 264-271. https://doi. org/10.1016/j.zefq.2012.03.002

NIES, Y. H., ISLAHUDIN, F., CHONG, W. W., ABDULLAH, N., ISMAIL, F., BUSTAMAM, R. S. A. et al. (2017) Treatment decision-making among breast cancer patients in Malaysia, Patient Preference and Adherence, 11: 1767-1777. https://doi.org/10.2147/PPA.S143611

OCK, M., YI, N., AHN, J. \& JO, M.-W. (2016) How many alternatives can be ranked? A comparison of the paired comparison and ranking methods, Value in Health, 19: 655-660. https://doi.org/10.1016/j.jval.2016.03.1836

PILE, E. (1964) The paired-comparison method: An evaluation aid for nurses, Journal of Psychosocial Nursing and Mental Health Services, 2: 492-496.

POLLARD, S., BANSBACK, N. \& BRYAN, S. (2015) Physician attitudes toward shared decision making: A systematic review, Patient Education and Counseling, 98(9): 10461057. https://doi.org/10.1016/j.pec.2015.05.004

ROBERTS, K. J. (2002) Physician-patient relationships, patient satisfaction, and antiretroviral medication adherence among HIV-infected adults attending a public health clinic, AIDS Patient Care and STDs, 16(1): 43-50. https://doi.org/10.1089/108729102753429398

ROBINSON, A. \& THOMSON, R. (2001) Variability in patient preferences for participating in medical decision making: Implication for the use of decision support tools, BMJ Quality \& Safety, 10: i34-i38. https://doi.org/10.1136/qhc.0100034

RODENBURG-VANDENBUSSCHE, S., PIETERSE, A. H., KROONENBERG, P. M., SCHOLL, I., VAN DER WEIJDEN, T., LUYTEN, G. P. et al. (2015) Dutch translation and psychometric testing of the 9-item shared decision making questionnaire (SDM-Q-9) and shared decision making questionnaire-physician version (SDM-Q-doc) in primary and secondary care, PLoS ONE, 10(7): e0132158. https://doi.org/10.1371/journal.pone.0132158

ROSS, K. G., KLEIN, G. A., THUNHOLM, P., SCHMITT, J. F. \& BAXTER, H. C. (2004). The recognition-primed decision model. Military Review, LXXIV, 6-10. 
ROSS, R. (1994) The ladder of inference, the fifth discipline fieldbook: Strategies and tools for building a learning organization (Sage Publisher, NY).

SANDHU, H., ADAMS, A., SINGLETON, L., CLARK-CARTER, D. \& KIDD, J. (2009) The impact of gender dyads on doctor-patient communication: a systematic review, Patient Education and Counseling, 76(3): 348-355. https://doi.org/10.1016/j.pec.2009.07.010

SANZ DE ACEDO LIZÁRRAGA, M. L., SANZ DE ACEDO BAQUEDANO, M. T. \& CARDELLE-ELAWAR, M. (2007) Factors that affect decision making: gender and age differences, International Journal of Psychology and Psychological Therapy, 7: 381-391.

SCHAEDE, U., MAHLICH, J., NAKAYAMA, M., KOBAYASHI, H., TAKAHASHI, Y., SAITO, K. et al. (2017) Shared decision-making in patients with prostate cancer in Japan: Patient preferences versus physician perceptions, Journal of Global Oncology, 4: 1-9. https://doi. org/10.1200/JGO.2016.008045

SHAHZAD, F., SALEEM, F., IQBAL, Q., HAQUE, N., HAIDER, S., SALMAN, M., et al. (2018) A cross-sectional assessment of health literacy among hypertensive community of Quetta City, Pakistan, Biomeical Journal of Scientific \& Technical Research, 11(4): 1-9. https://doi.org/10.26717/BJSTR.2018.11.002141

SHAY, L. A. \& LAFATA, J. E. (2014) Understanding patient perceptions of shared decision making, Patient Education and Counseling, 96(3): 295-301. https://doi.org/ 10.1016/j.pec.2014.07.017

SIDDHARTHAN, T., RABIN, T., CANAVAN, M. E., NASSALI, F., KIRCHHOFF, P., KALYESUBULA, R. et al. (2016) Implementation of patient-centered education for chronic-disease management in Uganda: an effectiveness study, PloS ONE, 11: 1-12. https://doi.org/10.1371/journal.pone.0166411

SINGH, J. A., SLOAN, J. A., ATHERTON, P. J., SMITH, T., HACK, T. F., HUSCHKA, M. M. et al. (2010) Preferred roles in treatment decision making among patients with cancer: a pooled analysis of studies using the control preferences scale, The American Journal of Managed Care, 16: 688.

SØRENSEN, K., VANDENBROUCKE, S., FULLAM, J., DOYLE, G., PELIKAN, J., SLONSKA, Z. et al. (2012) Health literacy and public health: a systematic review and integration of definitions and models, BMC Public Health, 12: 80. https://doi.org/10.1186/1471-2458-1280

STACEY, D., O'CONNOR, A. M., GRAHAM, I. D., \& POMEY, M.-P. (2006) Randomized controlled trial of the effectiveness of an intervention to implement evidence-based patient decision support in a nursing call centre, Journal of Telemedicine and Telecare, 12(8): 410-415. https://doi.org/10.1258/135763306779378663

STELlEFSON, M., DIPNARINE, K. \& STOPKA, C. (2013) Peer reviewed: The chronic care model and diabetes management in US primary care settings: A systematic review, Preventing Chronic Disease, 10: 1-21. https://doi.org/10.5888/pcd10.120180

Malay J Pharm Sci, Vol. 18, No. 1 (2020): 15-29 
STEWART, M. A. (1995) Effective physician-patient communication and health outcomes: a review, Canadian Medical Association Journal, 152: 1423-1433.

STREET JR, R. L. (1991) Information-giving in medical consultations: The influence of patients' communicative styles and personal characteristics, Social Science \& Medicine, 32(5): 541-548. https://doi.org/10.1016/0277-9536(91)90288-N

TAY, E., MASSARO, S. \& VLAEV, I. (2017) Toward a behavioral model of shared decision making, Academy of Management Proceedings, 2017(1): 1. https://doi.org/10.5465/ AMBPP.2017.13986abstract

ÜSTÜN, T. B., CHATTERJI, S., VILLANUEVA, M., BENDIB, L., ÇELIK, C., SADANA, R. et al. (2001) WHO multi-country survey study on health and responsiveness (Geneva: World Health Organization).

UZONWANNE, F. C. (2016) Influence of age and gender on decision-making models and leadership styles of non-profit executives in Texas, USA, International Journal of Organizational Analysis, 24(2): 186-203. https://doi.org/10.1108/IJOA-05-2013-0667

VEROFF, D., MARR, A. \& WENNBERG, D. E. (2013) Enhanced support for shared decision making reduced costs of care for patients with preference-sensitive conditions, Health Affairs, 32(2): 285-293. https://doi.org/10.1377/hlthaff.2011.0941

WHELAN, T., SAWKA, C., LEVINE, M., GAFNI, A., REYNO, L., WILLAN, A., et al. (2003) Helping patients make informed choices: a randomized trial of a decision aid for adjuvant chemotherapy in lymph node-negative breast cancer, Journal of the National Cancer Institute, 95(8): 581-587. https://doi.org/10.1093/jnci/95.8.581

WORLD HEALTH ORGANIZATION (WHO). (2016) Patient engagement: technical series on safer primary care, http://apps.who.int/iris/bitstream/handle/10665/252269/ 9789241511629-eng. pdf;jsessionid=1D8410E50CD9EF5339A109647AF79C3A ?sequence=1 (3 March 2019).

WICKRAMASINGHE, N., BALI, R. K., GIBBONS, M. C., CHOI, J. \& SCHAFFER, J. L. (2009) A systematic approach: optimization of healthcare operations with knowledge management, Journal of Healthcare Information Management, 23: 44-50.

WILLEMS, S., DE MAESSCHALCK, S., DEVEUGELE, M., DERESE, A., \& DE MAESENEER, J. (2005) Socio-economic status of the patient and doctor-patient communication: does it make a difference?, Patient Education and Counseling, 56(2): 139-146. https://doi. org/10.1016/j.pec.2004.02.011

YISHAI, Y. (2012). Participatory governance in public health: Choice, but no voice, IN: David L. -F. (Ed.) The Oxford handbook of governance. https://goi.org/10.1093/ oxfordhb/9780199560530.013.0037

YOUSUF, R., FAUZI, A., HOW, S., RASOOL, A. \& REHANA, K. (2007) Awareness, knowledge and attitude towards informed consent among doctors in two different cultures in Asia: A cross-sectional comparative study in Malaysia and Kashmir, India, Singapore Medical Journal, 48: 559-565. 